\title{
Students' English Language Learning Strategy and Implication to the Teaching and Learning Activity: A Study at Health Vocational Schools (SMK Kesehatan) in Ruteng at Flores Indonesia
}

\author{
Gabriel Fredi Daar \\ Faculty of Health Science, Universitas Katolik Indonesia Santu Paulus Ruteng, Flores, Indonesia \\ freddydaar@gmail.com \\ ${ }^{*}$ Corresponding Author \\ Whatsapp number: [081291726807]
}

How to Cite : Daar, G., F. (2019). Students' English Language Learning Strategy and Implication to the Teaching and Learning Activity (A Study at Health Vocational Schools (SMK Kesehatan) in Ruteng, Flores Indonesia). International Journal for Educational and Vocational Studies, 1 (6), 564-572

\section{ARTICLE HISTORY}

Received: 23 April 2019

Revised: 21 July 2019

Accepted: 18 September 2019

\section{KEYWORDS}

English Language;

Learning Strategy;

Teaching and Learning Activity;

\begin{abstract}
Different theorists proposed different definition of learning strategies (Wenden, 1987, O'Malley and Chamot, 1990, Oxford, 1990). All the definitions highlighted that learning strategies are the actions taken to make learning easier, faster, more enjoyable, more self-directed, more effective, and more transferrable. The study aims to find out how Health Vocational School students in Ruteng, Flores employ learning strategies, what strategy is mostly employed and the implications of learning strategy employed to language learning and teaching which cover cognitive strategy, meta cognitive strategy and social strategy. It's mixed method research combining the use of quantitative and qualitative study. For the purpose of quantitative study, it was chosen 123 students by using the technique of cluster random sampling, meanwhile for the purpose of qualitative data, it was chosen 12 students and three English teachers by using purposive sampling. The research result shows that students of health vocational schools in Ruteng, Flores employ medium language learning strategy for the three learning strategies studied (Cognitive strategy employed by $90,2 \%$ (111) students, meta cognitive strategy employed by $86,2 \%(106)$ students, and social strategy employed by $86,2 \%$ (106) students. Regarding learning strategy mostly employed, the most frequent strategy is cognitive strategy which gains the mean 3.33. Meanwhile, the least strategy is social strategy and it reaches the mean of 3.26. Medium learning strategy for the three strategies studied, and cognitive strategy as the most frequent strategy employed has the implication to applying teaching method which is oriented to raise up students' cognitive strategy, adopting regularly the meta cognitive instruction in the classroom to help students improve academic achievement, and providing the opportunity for students to practice speaking English out of the classroom.
\end{abstract}

This is an open access article under the CC-BY-SA license.

\section{INTRODUCTION}

The policy of learning English has been made by Indonesian government through education ministry to design curriculum which includes English as one of the compolsory subjects at Health Vocational Schools (SMK Kesehatan). It is obvious that government concerns the improvement of quality of learning outcome all over indonesia. It means that all Health Vocational Schools obtain the same chance to be assisted in all aspects that support language learning outcomes such as English teacher, English language laboratory, learning sources, etc.
Learning English at Health Vocational School (SMK Kesehatan) aims at providing students knowledge and competency in order to pass the test. Apart from it, the goal of learning English is providing the opportunity for the students to prepare themselves to use English as a medium of communication when contributing to health public services. More over, learning English aims at providing the chance to get preparation before going forward to higher education. Thus, to make learning objectives meaningful and achieveable, the supporting factors influencing the learning process and objectives could be considered during the learning process. 
All Health Vocational Schools (SMK Kesehatan) in Indonesia including in Ruteng, Flores have responded government's program through including English into the learning subject for three years, grade $\mathrm{X}$ to grade XII. It means that students have a lot of opportunity to learn English. Consequently, with its wide range of time, learning outcomes are supposed to achieve that students comprehend and master the four language skills (reading, writing, listening and speaking) and language aspects (grammar, vocabulary and pronunciation).

Some studies have proved that learning strategies bring an impact on the improvement of students' ability in English. A study on Effects of Learning Strategies upon Student Reading Literacy Performance conducted by Li and Chun (2012) showed that there is a positive relationship between learning strategy use and student reading performance, and that the memorization strategy has more strength in predicting students' reading performance than the elaboration strategy. Other study on learning strategy conducted by Biyikli and Dogan (2015) showed that learning strategies has higher effects on the variance in academic success point of students in the experimental groups that rehearsed daily at home what was learnt in class than on the variance in academic success point of students in the control group that did not rehearse daily at home what was learnt in class.

Even though students have a lot of opportunity to learn English, it is obvious that learning objectives haven't been gained maximally. Students don't have courage to express their idea orally in English, even in simple sentences. Moreover, students obtain bad scores in the mid-test, semester test, school test even national examination.

Based on the data published by national education department, the average scores of National English Test result achieved by NTT vocational school students are lower than what other provinces achieved. In scope of the regencies, the average scores achieved by vocational schools students in Manggarai regency are as follows 2015 is $54,15,2016$ is 57,68 , and 2017 is 42,25 , and to be more specific, the average scores obtained by Health Vocational Schools students in Manggarai regency are as follows; 2015 is 58.98, 2016 is 61,78 and 2017 is 45,61 (Puspendik Kemdikbud, 2017).

In order to cope with this problem, learning strategies must be taken into account. Students who are able to apply the kinds of strtategies as proved by the researchers obtain the benefits of achieving learning objectives such as mastering the target language and fulfilling the test. Brown (2000:122) stated that learning strategies refer to specific "attacks" that we make on a given problem. They are the moment by moment techniques that we employ to solve problems posed by language input and output. In correlation with this concept, some researches on non second language concentrating emotional and social side of learning indicated that a number of the best learners use affective and social strategies to control their emotion, to stay motivated, to cooperate and to get help (Dansereau, 1985, McCombs, 1988 in Brown, 2000: 125). By implementing such strategies, learners find that their learning objectives are achieved.

According to Wenden (1987:6 in Demirel \& Ügüten, 2015:93), learning strategies are "the techniques used to manipulate the incoming information, and later to retrieve what has been stored." O'Malley and Chamot (1990:1 in Demirel \& Ügüten, 2015: ibid) define learning strtaegies as "the special thoughts or behaviours that individuals used to help them comprehend, learn, or retain new information.". Moreover, Oxford (1990:8 cited in Sahin, 2005:11, and Demirel \& Ügüten 2015: ibid) says "Learning Strategies are specific actions taken by the learners to make learning easier, faster, more enjoyable, more self-directed, more effective, and more transferrable to new situations."

Learning strategies are very important for the learners, and they are supposed to posses their own strategy for the sake of achieving learning objectives. Chamot (2001:25 in Sahin, 2005:11, and Demirel \& Ügüten, 2015:ibid), stated that "learning strategies are important in the language learning process for two major reasons. First if the current strategies of learners are discovered, language learning process including cognitive, social, and affective processes will be understood. Second, identifying the strategy profile of foreign language learners will provide useful insights for training less successful learners who are thought to lack of the awareness of strategy use in the learning process." That is, identifying learning strategies is the key to diagnosis for lack of strategy use and cure towards self- awareness of strategy use which finally leads to autonomy.

Different theorists proposed different classifications of learning strategy. In this study, the writer concerns the classification of learning strategy proposed by Cohen. Cohen defined learning strategy as processes which are consciously selected by learners, consisting of cognitive strategies, meta-cognitive strategies, affective strategies and social strategies.

For the purpose of the study, the writer focuses only on three strategy classification as called Meta-cognitive strategies, social strategies and cognitive strategies. Meta-cognitive strategies deal with pre-assessment and preplanning, on-line planning and evaluation, and post-evaluation of language learning activities and of language use events. Cognitive strategies encompass the language learning strategies of identification, grouping, retention, and storage of language material, as well as the language use strategies of retrieval, rehearsal, and comprehension or production of words, phrases, and other elements of the second language. And Social strategies include the actions which learners choose to take in order to interact with other learners and with native speakers, such as clarification and cooperation (Cohen, 2000 in Liu 2010: 101-102). 


\section{METHODS}

The study was conducted at Health Vocational Schools (SMK Kesehatan) in Ruteng, Flores covering three Health Vocational Schools; Saint Matilda Health Vocational School, Elanus Health Vocational School and UIT Health Vocational School. In order to obtain research objective, it's used mixed method which combines the use of quantitative and qualitative study. The population of the study including grade XI Health vocational Schools students in Ruteng, Flores numbered 190 students. The students are still actively learning English as one of the compulsory subject. In order to achieve a valid and reliable result of the research, it's used cluster random sampling. The samples are taken randomly from different schools. For the purpose of questionnaire technique, it's used model of samples determination developed by Isaac and Michael with error level of $5 \%$. Therefore, 123 students were chosen as the samples of the research. Meanwhile, for the purpose of individual interview, it's chosen 12 students and 3 English teachers taken purposevely from different schools based on the following criteria:

a. Respondents have more knowledge and understanding on students language learning strategy.

b. Respondents have good ability in English proved by mid test or final test scores.

c. Respondents are willing to participate in the interview.

In collecting data, the writer uses questionnaire, individual interview, documentation, participative observation and Focus Group Discussion. The data then are analyzed quantitatively and qualitatively. The quantitative data are analyzed descriptively. The questionnaire contains three subscales of strategies (cognitive, metacognitive and social strtaegy) with a total of 80 items, and offered a choice of five Likert-scale responses for each strategy described: $1=$ never or almost never true of me, $2=$ generally not true of me, $3=$ sometimes true of me, 4=generally true of me, and $5=$ always or almost always true of me. The division of English language learning strategy is done through two techniques. First, Analysing the result of questionnaires to determine Median. Second, Median is used as the basic division of class category into three levels. To interpret the strategy frequency, the writer followed Schmenk, Schulze and Hamann's (2005) scale in Xiao (2007:145). That is, averages of 4.0-5.0 were considered exceptionally high strategy use; averages of 2.1-3.9 were regarded as medium and averages of 1.0-2.0 were designated as exceptionally low. Meanwhile the qualitative data are analyzed by implementing model of analysis proposed by Miles and Haberman consisting of data collection, data reduction, data display, and conclusion (Sugiyono, 2013). Test of data validity is done using test of data credibility, conducted through extending the observation, increasing the intensity of perseverance, discussing with others, analyzing negative case, member check, and applying conformability test.

\section{RESULTS AND DISCUSSION}

\subsection{Language Learning Strategy Employed by Health Vocational School Students in Ruteng, Flores}

There are three learning strategy classification explained and described in this part namely cognitive strategy, meta cognitive strategy and social strategy. In the first part, the writer shows the overall descriptive statistics of participants' response.

\subsubsection{Frequency and level of Language Learning of Cognitive} Strategies

Table 1. The frequency of language learning of cognitive strategy

\begin{tabular}{|c|c|c|c|c|}
\hline Item & Statement & Mean & SD & Strategy \\
\hline 1 & I try to guess what somebody is saying by using grammatical rules. & 3.0565 & 1.61448 & medium \\
\hline 2 & I learn English by watching English TV programs & 2.4355 & 1.40985 & medium \\
\hline 3 & I learn English by listening to English songs or other listening scripts & 3.2903 & 1.43007 & medium \\
\hline 4 & I try to understand what somebody is saying by translating into Indonesian & 3.6774 & 1.33464 & medium \\
\hline 5 & I draw an image or picture of the word in order to remember the word & 2.5610 & 1.58449 & medium \\
\hline 6 & I connect the pronunciation of the word with the Indonesian word which has a similar & 3.0887 & 1.39693 & medium \\
\hline 7 & I concentrate on the grammar rather than on the communication & 2.9194 & 1.32270 & medium \\
\hline 8 & I try to understand the idea by referring to previous experiences I have had & 3.1694 & 1.36579 & medium \\
\hline 9 & I try to guess by using a word (s) that is familiar to me & 3.6855 & 1.21887 & medium \\
\hline 10 & In Listening, I take notes to remember ideas & 4.1613 & 1.16443 & high \\
\hline 11 & I use rhymes to remember new English words & 2.5645 & 1.43273 & medium \\
\hline 12 & I try to remember new English words by pronouncing them & 3.6532 & 1.26905 & medium \\
\hline 13 & I speak a word or a sentence several times to remember it. & 3.7903 & 1.27052 & medium \\
\hline 14 & I try to learn a new pattern by making a sentence orally. & 3.1290 & 1.31265 & medium \\
\hline 15 & I try to translate Indonesian sentences into English sentences and produce them orally & 3.7500 & 1.40629 & medium \\
\hline 16 & I try to remember what the English word equivalent to Indonesian word is & 3.4032 & 1.37290 & medium \\
\hline 17 & I tape record the sentences I produce. & 2.8306 & 1.41261 & medium \\
\hline 18 & I mix Indonesian words and English words if I do not know the English words & 3.5806 & 1.42050 & medium \\
\hline 19 & I put words into rules that I know in speaking & 2.8629 & 1.39881 & medium \\
\hline 20 & Before I respond orally to questions, I write out the answers & 4.0565 & 1.08427 & high \\
\hline 21 & I try to correct my mistakes that I produce orally. & 3.7500 & 1.11621 & medium \\
\hline 22 & To understand unfamiliar English words while I am reading, I guess from available clues. & 2.5000 & 1.47334 & medium \\
\hline 23 & I learn English by reading English books or magazines. & 3.2419 & 1.31515 & medium \\
\hline
\end{tabular}




\begin{tabular}{|c|c|c|c|c|}
\hline 24 & I connect the spellings of English words with similar Indonesian words to understand. & 3.1290 & 1.33720 & medium \\
\hline 25 & I try to understand sentences by analyzing their patterns. & 2.9113 & 1.42573 & medium \\
\hline 26 & I try to translate word for word. & 4.0403 & 1.19891 & high \\
\hline 27 & I try to understand the passage by using my general knowledge and experience. & 3.5000 & 1.27834 & medium \\
\hline 28 & I use the key words to understand the whole ideas. & 2.8629 & 1.32723 & medium \\
\hline 29 & I read the passage aloud. & 3.2661 & 1.33196 & medium \\
\hline 30 & I take notes to remember the ideas. & 3.8065 & 1.22094 & medium \\
\hline 31 & While I read a text, I try to anticipate the story line. & 3.5968 & 1.20243 & medium \\
\hline 32 & I read a text more for ideas than words. & 3.1210 & 1.34704 & medium \\
\hline 33 & If I do not know how to express my ideas in English while writing, I keep writing using certain. & 3.0806 & 1.50661 & medium \\
\hline 34 & I write what I am thinking about. & 3.8710 & 1.08925 & medium \\
\hline 35 & I keep a diary. & 2.6532 & 1.40871 & medium \\
\hline 36 & I try to remember the meanings of words or the patterns by writing them & 3.3226 & 1.23333 & medium \\
\hline 37 & I write sentences to apply certain rules. & 3.1613 & 1.37567 & medium \\
\hline 38 & I try to translate word for word. & 3.8952 & 1.20850 & medium \\
\hline 39 & I mix Indonesian words and English words in writing. & 3.3952 & 1.46403 & medium \\
\hline 40 & I write the main ideas first as a guideline. & 3.2097 & 1.43291 & medium \\
\hline 41 & I use Indonesian words if I do not know the English words. & 3.6210 & 1.32881 & medium \\
\hline 42 & I use Indonesian patterns to keep writing in English. & 3.3952 & 1.39580 & medium \\
\hline 43 & I consult a dictionary to find out the meanings of words. & 3.9758 & 1.23935 & medium \\
\hline 44 & I write out new material over and over. & 3.0323 & 1.29373 & medium \\
\hline 45 & I try to memorize the meanings of words. & 3.8065 & 1.16645 & Medium \\
\hline
\end{tabular}

Table 1. shows the frequency of participants' response regarding the cognitive strategies they used. The item number 10 gains 4.16 as the mostly utilized strategy (In Listening, students take notes to remember ideas or material being learnt). The item number 2 gains 2.43 as the least chosen strategy by the students.

Table 2. Level of language learning of Cognitive Strategy

\begin{tabular}{cccccc}
\hline & & Frequency & Percent & \multicolumn{2}{c}{ Valid Percent } \\
\hline \multirow{3}{*}{ Valid } & Medium & 111 & 90,2 & 90,2 & 90,2 \\
\cline { 2 - 6 } & High Strategy & 12 & 9,8 & 9,8 & 100,0 \\
\cline { 2 - 6 } & Total & 123 & 100,0 & 100,0
\end{tabular}

Table 2 shows level of students' cognitive strategy. It can be seen that most students have medium cognitive strategy in learning English $(90,2 \%=111)$. There are only 9,8\% (12) students who have high strategy.

Based on the survey as stated in table 2, it was found that students take notes to remember ideas or material being learnt when dealing with Listening (item number 10) gains 4.16 or as the mostly utilized strategy. The finding was confirmed through the interview that the student always listens to English song through audio or video even every day. The student as well listens to English songs when he is studying English at school. English teacher provides English circumstance through listening session. Here is the subject's response:

"Saya Sering mendengarkan lagu Bahasa Inggris bahkan setiap hari. Saya memiliki motivasi untuk mencari lirik lagu Bahasa Inggris. Saya juga mendengarkan lagu Bahasa Inggris saat pelajaran.

\section{Translation:}

(I often listen to English songs every day. I have motivation to look for English songs lyric. I as well listen to Englisg song in the learning activity)" (DA: student).

On the other hand, learning English through watching English TV programs (item number 2) gains 2.43 as the least chosen cognitive strategy. The finding was confirmed through interview. Watching English program on TV was rarely done since he lives in the hostel and he doesn't possess supporting facility such as television. It also happens since he isn't able to manage time to watch English program. Here is the subject's response:

"Saya tinggal di kos-kosan. Saya tidak memiliki TV. Saya Jarang menonton program Bahasa Inggris di TV, dan terahir dilakukan pada bulan Desember 2017

\section{Translation:}

(I live in the hostel. I don't have TV. I seldom watch English program on $T V$, and the last time I watched $T V$ was in December 2017 " RA: student).

Dealing with habit of writing practice (item 35) 2,65 Subject doesn't have habit of writing daily journal. When the subject was interviewed, the subject said that he doesn't have daily journal which is written in Bahasa Indonesia even in English. It happened since the teacher doesn't provide the students opportunity to write daily journal using English. Here is the subject's response:

"Saya tidak memiliki jurnal harian apalagi yang saya tulis dalam Bahasa Inggris.

\section{Translation:}

(I don't have daily journal written in Bahasa Indonesia even in English” DR: student). 
On the other hand, the subject from other school has habit of writing daily journal even though it isn't consistently written in English. Sometimes the subject writes in Bahasa Indonesia. English teacher always asks them to write his experience in English. Here is the subject's response:

"Ya, siswa-siswi sering menulis kegiatan harian, mingguan dan bulanan.

\section{Translation:}

(Yeah, the students often write their daily, weekly and monthly activity)" (HM: English Teacher).

Student seldom does the practice of writing what's on his or her mind on social media like face book or writing experience he gets on that day. He does but only once or twice a week. However, English teacher always asks the students to practice writing in accordance with the experience they have. It is usually done in the teaching and learning process. Here is the subject's response:

"Ya ada, siswa- siswi sering dilatih menulis pengalaman dalam bahasa inggris.

\section{Translation:}

(Yeah, the students are often drilled to write experience in English" HM: English Teacher).

According to Oxford (1990) cognitive strategies are built up of four sets of learning strategies such as; practicing, receiving and sending messages, analyzing and reasoning, and creating structure for input and output. These strategies are necessary for both comprehension and production in the new language. These cover taking notes, summarizing, and highlighting. If it refers to Oxford definition, health Vocational school students in Ruteng employ part of four sets of cognitive learning strategy. The students only build the sets of practicing and sending messages. They haven't employed the sets of analyzing, reasoning even creating structure. It is in line with the level of cognitive strategy gained is that most students have medium cognitive strategy in learning English $(90,2 \%=106)$. There are only 9,8\% (12) students who have high strategy in learning English (Table 4.3).

\subsubsection{Frequency and Level of Language Learning of Meta Cognitive Strategies}

Table 3. The frequency of language learning of meta cognitive strategy

\begin{tabular}{|c|c|c|c|c|}
\hline Item & Meta cognitive Strategy & Mean & SD & Strategy \\
\hline 1 & I try to understand every individual word to understand the passage & 3.8468 & 1.18969 & medium \\
\hline 2 & I listen to what I say to practice my listening skill & 3.2177 & 1.40591 & medium \\
\hline 3 & Before practicing my listening skill, I prepare a topic, pronunciation or grammatical & 3.1532 & 1.36771 & medium \\
\hline 4 & I try to remember a sentence(s) spoken face-to-face or on cassettes and analyze them & 2.7661 & 1.55186 & medium \\
\hline 5 & After a listening practice, I check and recheck my understanding & 3.5887 & 1.29422 & medium \\
\hline 6 & I try to speak with myself to improve my speaking. & 3.4919 & 1.26553 & medium \\
\hline 7 & I try to evaluate my utterances after speaking. & 2.9677 & 1.34911 & medium \\
\hline 8 & I notice my English mistakes, and use that information to help me do better. & 3.1935 & 1.25379 & medium \\
\hline 9 & I prepare a topic or grammatical rules in speaking practice. & 2.7500 & 1.47403 & medium \\
\hline 10 & I ask somebody to correct me when I talk. & 3.4355 & 1.41560 & medium \\
\hline 11 & I practice speaking with my friends or my teachers. & 3.5645 & 1.25096 & medium \\
\hline 12 & I correct my mistakes by rereading the text. & 3.7016 & 1.38505 & medium \\
\hline 13 & I choose a topic or certain materials for my practice. & 3.0565 & 1.37517 & medium \\
\hline 14 & I check and recheck my understanding after reading a passage. & 3.5565 & 1.28343 & medium \\
\hline 15 & If I cannot understand a reading passage, I try to analyze what difficulty I actually have. & 3.4274 & 1.28894 & medium \\
\hline 16 & In reading, I pick out key words and repeat them to myself. & 3.3871 & 1.35376 & medium \\
\hline 17 & I try to be aware of which words or grammar rules give me the greatest trouble & 3.2661 & 1.35616 & medium \\
\hline 18 & I rewrite my composition by correcting the mistakes that I notice. & 3.1290 & 1.36130 & medium \\
\hline 19 & I choose a topic to improve my writing skill. & 2.9274 & 1.41521 & medium \\
\hline 20 & I read my writing and correct the mistakes. & 3.5806 & 1.14832 & medium \\
\hline 21 & I try to be aware of which words or grammar rules give the greatest trouble, this way I. & 3.2339 & 1.39166 & medium \\
\hline
\end{tabular}

Table 3 shows the frequency of participants' response regarding the meta cognitive strategies they used. The item number 1 gains 3.84 as the mostly utilized strategy (In reading, students try to understand every individual word to understand the passage). The item number 9 gains 2.75 as the least chosen strategy by the students. 
Table 4. Level of language learning of Meta cognitive Strategy

\begin{tabular}{|c|c|c|c|c|}
\hline & Frequency & Percent & Valid Percent & Cumulative Percent \\
\hline Medium & 106 & 86,2 & 86,2 & 86,2 \\
\hline High Strategy & 17 & 13,8 & 13,8 & 100,0 \\
\hline Total & 123 & 100,0 & 100,0 & \\
\hline
\end{tabular}

Table 4 shows level of students' meta cognitive. It can be seen that most students have medium Meta cognitive strategy in learning English (86,2\%=106). There are only 13,8\% (17) students who have high strategy.

Based on the survey as stated in table 4, it was found that item number 1 (mean=3.84) as the mostly utilized strategy (In learning reading, students try to understand every individual word to understand the passage). The finding was confirmed through interview that student does so when he reads English books, articles or newspapers though doing it when he is in the teaching and learning process in the classroom. Subject reads after getting instruction from the English teacher. In the context of practice reading aloud, student reads a paragraph or text loudly when he is learning English in the classroom. Here is the subject's response:

"Saya selalu membaca artikel dan buku Bahasa inggris pada saat les Bahasa Inggris. Saya juga melakukan praktik membaca saat di rumah. Terkait membaca bersuara, saya beberapa kali membaca bacaan Bahasa Inggris dengan lantang saat les Bahasa inggris.

\section{Translation:}

(I always read article and English book in English class. I as well do so at home. Regarding raedin aloud, I do reading a loud a few times in the English class" GH: student).

It is supported by the information given by the English teacher that students are sometimes given opportunity to practice reading aloud which is oriented to improve the students' ability of pronunciation. Here is the subject's response:

"Ya, siswa sering dilatih untuk membaca dengan suara lantang saat mendiskusikan teks Bahasa Inggris.

\section{Translation:}

(Yeah, the students are often asked to practice reading aloud when it's time to learn or discuss a text." (HM: English Teacher).

On the other hand, student prepares a topic or grammatical rules in speaking practice (item 9) gains 2.75 as the least chosen strategy by the students. The finding was confirmed through interview that practice speaking English to him or herself is hardly done by the subject. Certain subject sometimes does it but in the context of involving in the conversation practice with his or her friends. Practice speaking to the classmates or teachers was undertaken by the subject, but it is only done during English class. Teachers provide students circumstances for taking part in the dialogues or conversations created by the students themselves. This is done for improving the ability of speaking. Here is the subject's response:
"Saya tidak pernah melakukan praktik berbicara dengan diri saya sendiri dalam Bahasa Inggris. Saya berbicara Bahasa Inggris tetapi dengan teman saya. kami sering melakukan praktik dialog Bahasa Inggris pada saat pelajaran Bahasa Inggris. Selain itu, kami juga melakukan praktik berbicara dengan guru. Dialog tersebut kami lakukan untuk meningkatkan kemampuan berbicara Bahasa Inggris kami."

\section{Translation:}

(I never practice speaking English to myself. I do the practice to my classmates in the learning activity. Moreover, we do the speaking practice with our teacher. The practice is undertaken to improve our speaking ability" ET: students).

Practice speaking through dialogue or conversation then is more useful and obtaining great effects on the improvement of students speaking ability as school provides "English Day" program which obliges all students and teachers to speak in English on that day.

"Di sekolah praktik berbicara Bahasa Inggris dengan sesama siswa dan dengan guru sering dilakukan karena sekolah menerapkan program "English Day" untuk murid dan guru.

\section{Translation:}

(Practice speaking in English to classmates or other students and teachers is always done as school provides English day "(TH: English teacher).

Demirel and Üğüten (2015) said that meta cognitive strategies are indispensible for successful language learning. They make students more aware of their own learning process. When the students think about their own learning, they develop self-awareness and finally learner autonomy is improved. The use of meta cognitive strategy enhance autonomy and self-awareness of the students in learning and give them the responsibility of their own learning. The study found that the students hardly ever practice speaking or reading by himself or herself as the implementation of autonomy except in the context of opportunity given by the teachers or under instruction. It is in line with the level of language learning of meta cognitive strategy gained is that most students have medium Meta cognitive strategy in learning English (86,2\%=106), and only $13,8 \%$ (17) students who have high strategy in learning English (table 4.5). The students don't think about their own learning, and consequently they aren't able to develop self-awareness which in the final phase they cannot be autonomous learners. 
It's obvious that the use of meta cognitive strategy isn't only to enhance autonomy and self-awareness of the students in learning but also to enhance student's academic achievement. It's in line with the study conducted by Jayapraba (2013) which revealed that meta cognitive instructions were most effective in enhancing academic achievement. Jayapraba then recommended that meta cognitive instruction be adopted regularly in the classroom so as to help students learn material more efficiently and enhance academic achievement.

\subsubsection{Frequency and Level of language Learning of Social Strategy}

Table 5. The frequency of language learning of social strategy

\begin{tabular}{|c|c|c|c|c|}
\hline Item & Social Strategy & Mean & SD & Strategy \\
\hline 1 & I correct the mistakes that I produce orally & 3.4839 & 1.27823 & medium \\
\hline 2 & I try to be aware of which sounds give the greatest trouble. In this way I can pay & 3.1532 & 1.53042 & medium \\
\hline 3 & If I cannot understand what somebody is saying, I ask him/her to slow down or say it & 4.1855 & .99892 & high \\
\hline 4 & Listening to what somebody is saying improves my listening skill & 3.4919 & 1.25909 & medium \\
\hline 5 & In a group discussion, my listening skill is improved & 3.6935 & 1.26348 & medium \\
\hline 6 & I practice English with native speakers. & 2.3145 & 1.43344 & medium \\
\hline 7 & I ask questions in English. & 2.6210 & 1.38278 & medium \\
\hline 8 & If I cannot think during a conversation in English, I use gestures. & 2.5887 & 1.56700 & medium \\
\hline 9 & I discuss reading passages with my friends. & 3.7258 & 1.19170 & medium \\
\hline 10 & If I do not understand the content of a reading passage, I ask my friends or my teachers & 3.7016 & 1.43124 & medium \\
\hline 11 & I improve my reading skill by reading letters from my friends. & 3.1129 & 1.47725 & medium \\
\hline 12 & I write a message to my friends in English for practice. & 3.1210 & 1.42334 & medium \\
\hline 13 & I write letters in English to my friends. & 2.9919 & 1.39974 & medium \\
\hline 14 & I ask my friends or my teachers to correct my writing. & 3.3145 & 1.51076 & medium \\
\hline
\end{tabular}

Table 5 shows the frequency of participants' response regarding the social strategy they used. The item number 3 gains 4.18 or as the mostly utilized strategy (In speaking, students ask the speaker to repeat what he is saying if he doesn't understand). The item number 6 gains 2.31 as the least chosen strategy.

Table 6. Level of language learning of Social Strategy

\begin{tabular}{llrrrrr}
\hline & & Frequency & & Percent & Valid Percent & \multicolumn{2}{c}{ Cumulative Percent } \\
\hline \multirow{2}{*}{ Valid } & Low Strategy & 1 &, 8 &, 8 &, 8 \\
\cline { 2 - 7 } & Medium & 106 & 86,2 & 86,2 & \\
\cline { 2 - 7 } & High Strategy & 16 & 13,0 & 13,0 & 100,0 \\
\cline { 2 - 7 } & Total & 123 & 100,0 & 100,0 & \\
\hline
\end{tabular}

Table 6 shows level of students' social strategy. It can be seen that most students have medium social strategy in learning English $(86,2 \%=106)$. There are only $13,0 \%$ (16) students who have high social strategy.

Based on table 6, It was found that most students have medium social strategy in learning English $(86,2 \%=106)$. There are only $13,0 \%$ (16) students who have high social strategy in learning English. Frequency of language learning of social strategy analyzed by items as stated in table 6 found that item number 3 gains 4.18 as the mostly utilized strategy (Student asks the speaker to repeat or slower what he has said if he cannot understand). The students do so only in the context of practice speaking under teacher's instruction. Most of the students hardly ever practice speaking as the implementation of self awareness and autonomy. The students do the practice when the teacher asks them to. Item number 6 gains 2.31 as the least chosen strategy (I practice English with native speakers). This finding is in line with interview result that practice speaking to the native speaker of English is hardly ever done by the subjects. From the total of 15 subjects, one teacher created the circumstance where students can practice speaking with the native speaker of English. As it has been designed by the school, the teacher usually invites the native speaker of English to the classroom and let the students practice speaking with him or her. Here is the subject's response
"Ya, saya mendukung siswa saya untuk berlatih berbicara Bahasa Inggris dengan membawa bule ke dalam kelas.

\section{Translation:}

(I support my students to practice speaking by inviting native speaker to the classroom" TH: English teacher).

Regarding the students' involvement in the discussion, English teacher always asks them to do so, however they don't use English as the medium of communication. In the discussion, subject just learns the vocabulary translation into Bahasa Indonesia. The subject even learns English passively by listening to what the teacher is saying. Most discussions activity are done under English teacher's design and instruction.

Though the students do practice under the teacher's instruction, however it deserves appreciation, and continuously encouraged. In short term of practice, the students at least involve in social interaction which brings an impact on improving shelf confident to do the next practices. Cohen (2000 in Liu 2010:102) stated that social strategies include the actions which learners choose to take in order to interact with other learners and with native 
speakers, such as clarification and cooperation. By doing a step by step of practice, students choose to go out of himself or herself, find the best model of practice which make him able to be a good speaker of English.

\subsection{Language Learning Strategy Mostly Employed by Health Vocational School Students in Ruteng, Flores}

Table 7. The frequency of language learning used by Health Vocational School Students

\begin{tabular}{cccc}
\hline Strategy & Mean & SD & Strategy Use \\
\hline Cognitive strategy & 3.33 & .45317 & medium \\
\hline Meta cognitive Strategy & 3.30 & .53295 & medium \\
\hline Social Strategy & 3.26 & .56928 & medium \\
\hline
\end{tabular}

Table 7 shows the frequency of participants' response regarding the overall strategies they used. The most frequent strategy is cognitive strategy which gains 3.33. Meanwhile, the least strategy is social strategy and it reaches the mean of 3.26

According to Cohen (2000 in Liu, 2010: 102), language learning and language use strategies are defined as processes which are consciously selected by learners. Language learning strategies, which are used with an explicit goal of improving learner knowledge of given language, are composed of cognitive strategies, meta-cognitive strategies, affective strategies and social strategies. Cognitive strategies encompass the language learning strategies of identification, grouping, retention, and storage of language material, as well as the language use strategies of retrieval, rehearsal, and comprehension or production of words, phrases, and other elements of the second language. What Cohen proposed is actually to support what Oxford has stated. Oxford (1990 in Liu, 2010:101) stated that cognitive strategies, such as analyzing and reasoning, are used for forming and revising internal mental modes and receiving and producing messages in the target language.

The study found that most Health Vocational School students in Ruteng employ cognitive strategy which gains 3.33. Meanwhile, the least strategy is social strategy and it reaches the mean of 3.26 (Table 7 ). The findings then are described in accordance with cognitive strategy definition as proposed by Oxford encompass analyzing and reasoning, and receiving and producing the target language.

The activity of analyzing and reasoning is performed by the students in doing the translation. Students do the practice of translating English words or sentences into Bahasa Indonesia though it was undertaken when it's English class. Sometimes the students do such activity out of the class when there was English assignment given by the teacher. It is as well performed through reading English books, articles or newspapers in the teaching and learning process, discussing and answering the questions based on the text, and reading a text loudly when the students are given opportunity to practice reading aloud which is oriented to improve the students' ability of pronunciation.

The activity of receiving and producing is performed by the student through listening and writing. Student listens to English songs every day through audio or video provided by his own. Student as well listens to English song when he is studying English at school. English teacher provides English circumstance through listening session. In producing English, student does the practice of writing what's on his or her mind on social media like face book or writing experience he gets on that day. He does it once or twice a week. It is supported by English teacher by asking them to practice writing in accordance with the experience they have. It is usually done in the teaching and learning process. Student also has habit of writing daily journal even though it isn't consistently written in English. Sometimes the student writes in Bahasa Indonesia.

\subsection{Learning strategies Implications to Language learning and teaching at Health Vocational Schools in Ruteng, Flores}

Based on the research results and discussion, most students have medium strategy for the three strategy classification; cognitive, meta cognitive and social strategy, and the most frequent strategy performed by students is cognitive strategy. There are some implications that should be undertaken during the teaching and learning process:

First, English language teachers are supposed to be able to apply teaching method which is oriented to arise students' cognitive strategy. In the early stages, teachers apply some techniques of receiving by focusing on the listening and reading. In this stage, students are introduced words, phrases, sentences even paragraphs without asking them to produce anything. In reading practice, students are introduced spelling and how to pronounce words. In the later stages, English teachers apply some techniques of producing through speaking and writing. In learning speaking, students are asked to involve in dialogue practice, role play, storytelling and other techniques which aim to improve students speaking ability. In learning writing, students are asked to write daily activities, write experience, write letter even write daily journal which aim to improve students' writing ability. Teachers as well create learning situation where students can perform the activity of analyzing through translation, answering questions based on the text and practice writing in advanced phase. Second, students hardly ever do practice of speaking or reading or writing by self awareness. It is the English teacher and school's responsibility to guide 
and lead students to be autonomous learners of English. Becoming autonomous learners is the final orientation of employing meta cognitive strategy, and when the students become aware of their own learning, the students can learn material more efficiently and enhance their academic achievement (Jayapraba, 2013). Thus, it's recommended that meta cognitive instruction be adopted regularly in the classroom so as to help students improve academic achievement in mid test or final test. Third, social strategy is the least frequency strategy among the three strategies studied, and practice speaking English with native speaker is the least chosen strategy. It is contrary to the goal of language learning is that to gain the ability of communicating with others which happens in social context. To this extend, schools authority should provide the opportunity for students to practice speaking English out of the classroom. It can be applied through English Day, inviting native speaker to the school, school trip and other kinds of activity which is oriented to make students speak up.

\section{CONCLUSION}

Based on the findings, it was found that students of health vocational schools in Ruteng, Flores employ medium language learning strategy for the three learning strategies studied (Cognitive strategy employed by 90,2\% (111) students, meta cognitive strategy employed by $86,2 \%(106)$ students, and social strategy employed by $86,2 \%$ (106) students. Regarding learning strategy mostly employed, the most frequent strategy is cognitive strategy which gains the mean 3.33. Meanwhile, the least strategy is social strategy and it reaches the mean 3.26. Medium learning strategy for the three strategies studied, and cognitive strategy as the most frequent strategy employed has the implication to applying teaching method which is oriented to raise up students' cognitive strategy, adopting regularly the meta cognitive instruction in the classroom to help students improve academic achievement, and providing the opportunity for students to practice speaking English out of the classroom.

\section{REFERENCES}

Biyikli, Cemal and Nuri Dogan. (2015). The effect of learning strategies used for rehearsal on the academic success. Education and Science 2015, Vol 40, No $\quad 311327$. https://www.researchgate.net/publication/283859528 _The_Effect_of_Learning_Strategies_Used_for_Rehe arsal_on_the_Academic_Success

Brown, H. Douglas. (2000). Principles of Language Teaching and Learning. New York: A pearson Education Company.

Demirel, Eda Ercan \& Selma Durak Ügüten. (2015). Using Learning Strategies To Foster Autonomy. International Journal of Language Academy, Volume
3/4 Winter. http://dx.doi.org/10.18033/ijla.343.

Retrieved, October 5, 2017.

Firima Zona Tanjung. (2018). Language Learning Strategies in English as a Foreign Language Classroom in Indonesian Higher Education Context. Vol. 21, Suppl, June 2018. http://e-journal.usd.ac.id/index.php/LLT/article/view/ 966/pdf

Gajalakshmi. (2013). High School Students' Attitude towards Learning English Language. International Journal of Scientific and Research Publications, Volume 3, Issue 9, September 20131 ISSN 2250-3153. www.ijsrp.org. Retrieved October 5, 2017.

Jayapraba, G. (2013). Metacognitive Instruction and Cooperative Learning- Strategies for Promoting Insightful Learning in Science. International Journal on New Trends in Education and Their Implications January 2013 Volume: 4 Issue: 1

Kementerian Pendidikan dan Kebudayaan. (2017). Pusat Penilaian Pendidikan. https://ubk.kemdikbud.go.id/

Li, Jie and Cecilia Ka-Wai Chun. 2012). Effects of Learning Strategies on Student Reading Literacy Performance. Volume 12, Number 1, April 2012. http://www.readingmatrix.com/articles/april_2012/li _chun.pdf

Liu, Jing. (2010). Language Learning Strategies and Its Training Model. International Education Studies, Vol. 3, No. 3; August 2010

Setiyadi, Ag Bambang. (2014). Skill-Based Categories: An Alternative of Language Learning Strategy Measurement. ISSN 1798-4769 Journal of Language Teaching and Research, Vol. 5, No. 2, pp. $360-370$

Sugiyono. (2013). Metode Penelitian Pendidikan; Pendekatan Kualitatif, Kuantitatif, dan R\&D. Bandung: Alfabeta

Xiao, Junhong. (2007). Language Learning Strategies in Distance English Learning: A Study of Learners at Shantou Radio and Television University, China. The Journal of Asia TEFL, Vol. 4, No. 2, p. 141-164.

Wolters, Bernadette van Hout and Gonny Schellings. (2009). Measuring Learning Strategies: Different measurement methods and their usability in education and research. University of Amsterdam. www.http://researchgate.net. Retrieved April 5, 2018. 